\title{
Soil transformations in catchment of disappearing Sumówko Lake (Brodnickie Lake District, Poland)
}

\author{
Sławomir S. Gonet ${ }^{1}$, Maciej Markiewicz ${ }^{1}$, Włodzimierz Marszelewski ${ }^{2}$, Andrzej Dziamski ${ }^{3}$ \\ ${ }^{1}$ Nicolaus Copernicus University, Department of Soil Science, Gagarina 9, 87-100 Toruń, Poland, e-mail: mawicz@umk.pl \\ ${ }^{2}$ Nicolaus Copernicus University, Department of Hydrology and Water Management, Gagarina 9, 87-100 Toruń, Poland, \\ e-mail: marszel@umk.pl \\ ${ }^{3}$ University of Technology and Life Sciences, Department of Botany, Bydgoszcz, Poland
}

\begin{abstract}
Lake disappearing is a natural process which contemporarily escalates in consequence of human activity. It is estimated that within the area of Northern Poland from the last glaciation period (ca. 17000 years ago) a half of lakes totally have disappeared. Areas exposed after water basins desiccation have become native rocks for new soils. Reduced water level results in changes of morphology and properties of the soils situated in direct vicinity of former water basins. The aim of this study was to estimate impact of the catchment groundwater level fall on morphology and properties of direct lake catchment soils, exemplified by the lake Sumowko (Northern Poland) as well as description of new soils formed of lake sediments. The analysis covered 11 soil profiles emerging within former lake basin (newly formed soils) and soils from direct vicinity of former lake (modified through ground water level fall). Obtained results prove that newly formed soils (Limnic Histosol Drainic and Haplic Gleysol) in majority are utilized as grasslands. Soils of the former lake surroundings prove relic features of gleying while they are also subject to mucking process because of dehydration.
\end{abstract}

Key Words: Lake demise, lake catchment, gyttia soils, soil morphology

\section{Introduction}

Lakes are rated among the most sensitive natural scenery elements which relatively quickly respond to any changes undergoing in natural environment. They have undergone numerous development stages in the process of evolution; many of them have led to lakes demise. Particularly, it pertains to early post-glacial areas where the greatest and fastest morphometric changes occur.

Regions of former lakes constitute more than a half of total surface area of all early post-glacial Polish lakes (Kalinowska 1961; Marszelewski 2005). Most of the lakes have passed away within the recent several thousand years, mainly owing to natural factors (Churski 1998). A violent acceleration of lake disappear process in consequence of human activity (marsh drainage and reduction of lake water levels with the aim of new meadows and pastures acquisition as well as channel construction and creation of water transport routes) has been evident in last 100-200 years.
As a result, water-free areas increase their scope and groundwater levels fall. Consequently, also soil morphology and properties in those areas change rapidly. Water is very important factor in soil formation. In some cases (e.g. Histosols or Gleysols) it conditions their emergence, whereas formation of autogenic soils often gets modified under occurrence of groundwater which adds properties of gley processes to the core soil formation process.

The issue of organic soils dehydration has been relatively well investigated while only few studies have concerned evolution of mineral soils owing to groundwater level fall related to lake demise. Such transformations are likely to affect soil usability and therefore stimulate ways of those soils development. This problem is closely related with loss of organic carbon in soils of the world (Gonet and Markiewicz 2007).

The aim of this study was to estimate the impact of dramatic lake water level decrease and groundwater level fall on morphology and properties of disappear- 
ing lake Sumówko direct catchment soil as well as describe soils newly formed of lake sediments.

\section{Study area}

The study area was located in direct catchment (18.3 ha in area) of the lake Sumówko, Brodnickie Lake District, situated on the border of Brodnica Landscape Park, Northern Poland (Figure 1 and 2). Local landform features result from the last Baltic glaciations; it is diverse moraine scenery with numerous kettle holes and ribbon lakes. From the moment of such lie of land emergence (ca. 17000 years ago) a slow process of lakes demise has taken place in this area (Niewiarowski 1986).

Brodnica Lake District climate, the same as in the whole Polish Lowlands, features significant variability and temporariness which results from the location between marine climate areas and continental climate ones. Mean annual temperature ranges from 7.0 to $7.5^{\circ} \mathrm{C}$ and the mean annual precipitation slightly exceeds $500 \mathrm{~mm}$.
The investigation took place in the catchment of kettle lake Sumówko which surface area has decreased of $72.6 \%$ from 1860 . In years $1860-1874$ it was still a single reservoir while at present it comprises two basins of 17.6 ha and 10.1 ha in area.

\section{Methods}

There were 4 transects set in direct catchment. Within their scope a total of 11 soil profiles were executed. Profiles' morphology and soil type were estimated according to standard procedures. In the soil samples from genetic horizons were estimated: particle size distribution by hydrometer method according to Bouyocos as modified by Casagrande and by Prószyński (sand and gravel were separated on sieves), $\mathrm{pH}$ value by glass electrode in 1:2.5 soil/water and 1:2.5 soil/ KCl suspensions of concentrations $1 \mathrm{~mol} \mathrm{l}^{-1}$, losses of ignition (LoI), total content of organic carbon (TOC) by oxidation with potassium dichromate, total nitrogen $(\mathrm{Nt})$ by Kjeldahl method and carbonates $\left(\mathrm{CaCO}_{3}\right)$ by Scheibler method (Table 1). The colours

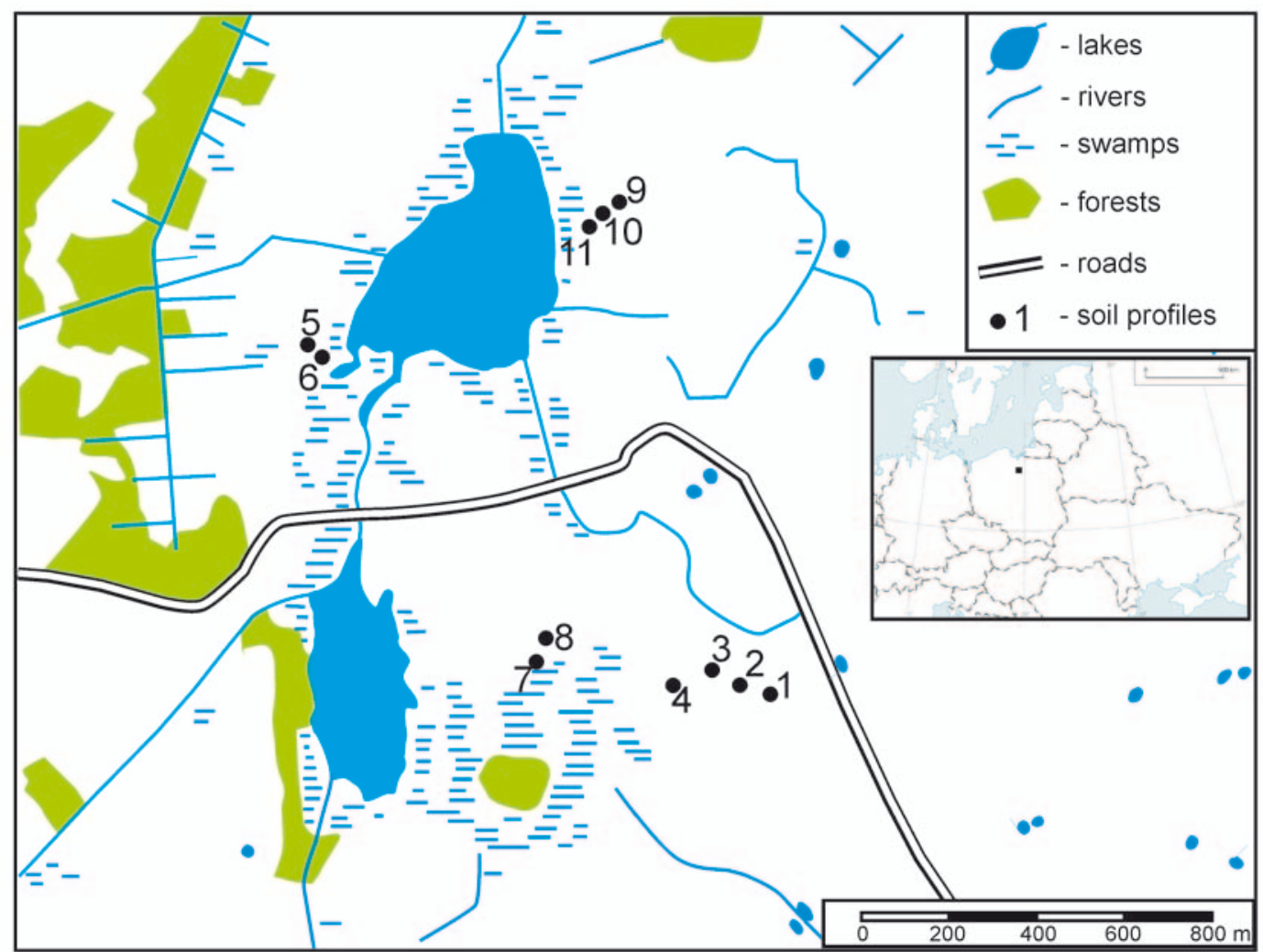

Fig. 1. Localization of the study area 


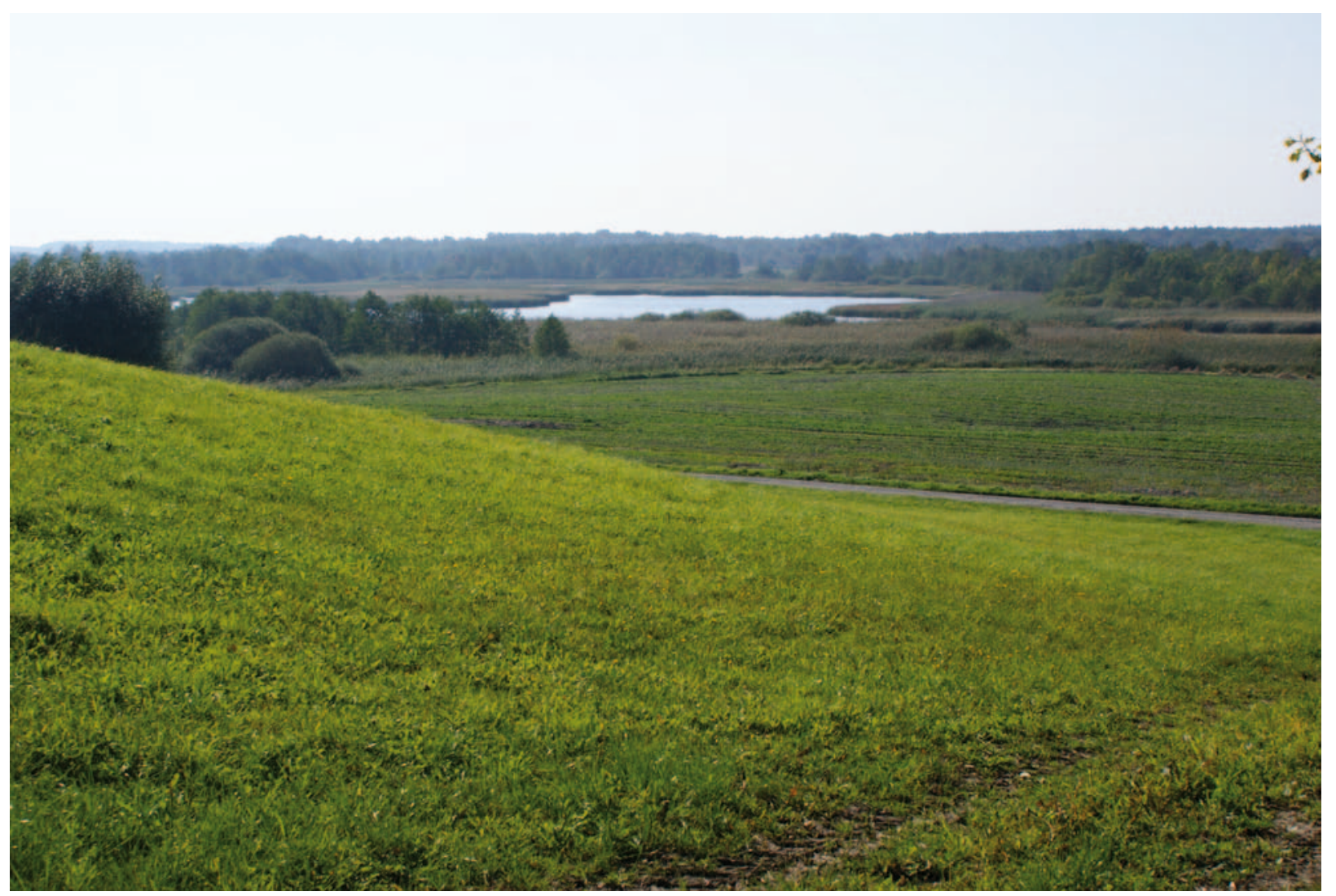

Fig. 2. Sumówko lake

of dry and mist samples were keyed to the Munsell Soil Colour Charts. The soil description were taken under Guidelines for soil description (FAO 2006). The names of soils were based on WRB (2006).

\section{Results and discussion}

Soils of direct catchment of lake Sumowko features mosaic-like nature which relates to significant diversity of surface formations and variable water relations. Upland is mainly covered with Luvisols and Mollic Gleysols. Sandy eskers have become native rocks for Brunic Arenosols and concurrent mucky soils (Areni Mollic Gleysol) that occur in more moist depressions. Soil cover of former lake basin is represented by Histosols and gyttia soils (Limnic Histosol Drainic). In places of minor peat horizon mucky soils have been formed. Also Colluvic Regosols occur here abundantly. Analysed soils may be divided into two groups: (i) emerging within the former lake basin (profiles 4, 7 in southern lake, and 5, 6 in northern lake) and (ii) soils of direct surroundings of former lake (other profiles). Other authors obtained similar results (Markowski 1980; Tobolski 2000).

Soils formed of bottom sediments are distinguished by content of various thickness gyttia horizons (profiles 4 and 7) or mineral matter originated in former lake wave zone (profiles 5 and 6). After the lake water level had significantly fallen such sediments became parent material for soils that often as a result of anthropogenic denudation have been covered with colluvial formations. Gyttia of investigated area features alkaline reaction, high content of carbonates (818 $\mathrm{g} \mathrm{kg}^{-1}$ in profile no. 4) and content of organic carbon of ca. $60 \mathrm{~g} \mathrm{~kg}^{-1}$ (Table 1). These soils additionally prove ground-water gleying marks. Furthermore, groundwater often occurs within the profile (particularly in spring months).

Soils situated above the former lake coastline are distinguished by occurrence of ground-water gleying marks (profiles 9,10,11), often of relic properties. They are mostly Haplic Gleysols that similarly were covered with various thickness colluvial matter (profiles $1,9,11$ ). Colluvia resulted from intensive farming 
Table 1. Properties of soils of transect 1 and 2 by the lake Sumowko (southern part)

\begin{tabular}{|c|c|c|c|c|c|c|c|c|}
\hline \multirow{2}{*}{ Horizon } & \multirow{2}{*}{$\begin{array}{c}\text { Depth } \\
(\mathrm{cm})\end{array}$} & \multirow{2}{*}{ Lol } & \multirow{2}{*}{$\begin{array}{l}\text { TOC } \\
\mathrm{g} \mathrm{kg}^{-1}\end{array}$} & \multirow{2}{*}{$\mathrm{Nt}$} & \multirow[b]{2}{*}{$\mathrm{C}: \mathrm{N}$} & \multicolumn{2}{|c|}{$\mathrm{pH}$} & \multirow{2}{*}{$\begin{array}{l}\mathrm{CaCO}_{3} \\
\left(\mathrm{~g} \mathrm{~kg}^{-1}\right)\end{array}$} \\
\hline & & & & & & in $\mathrm{H}_{2} \mathrm{O}$ & in $\mathrm{KCl}$ & \\
\hline \multicolumn{9}{|c|}{ Transect 1, profile 1 - Brunic-Arenosol } \\
\hline Ap & $0-51$ & 10 & 7.6 & 0.61 & 13 & 4.4 & 3.8 & - \\
\hline Bw & $51-85$ & 4 & 1.2 & 0.09 & 13 & 5.7 & 4.7 & - \\
\hline $\mathrm{C}$ & $85-125$ & 3 & 0.6 & 0.05 & 12 & 6.3 & 5.0 & - \\
\hline \multicolumn{9}{|c|}{ Transect 1 , profile 2 - Mollic-Gleysol-Drainic } \\
\hline A & $0-41$ & 57 & 33.5 & 2.40 & 14 & 6.5 & 5.8 & - \\
\hline $\mathrm{Cr}$ & $41-85$ & 4 & 1.5 & 0.13 & 12 & 6.7 & 5.7 & - \\
\hline \multicolumn{9}{|c|}{ Transect 1, profile 3 - Histosol-Drainic } \\
\hline A & $0-100$ & 107 & 53.1 & 0,459 & 12 & 7.4 & 6.9 & 2.7 \\
\hline Oi & $100-120$ & 764 & 422 & 2,052 & 21 & 6.5 & 6.1 & - \\
\hline $\mathrm{Cr}$ & $120-140$ & 58 & 35.7 & 0,205 & 17 & 7.8 & 7.4 & 252 \\
\hline \multicolumn{9}{|c|}{ Transect 1, profile 4 - Limnic-Histosol-Drainic } \\
\hline Oi & $0-29$ & 662 & 327 & 23.02 & 14 & 6.8 & 6.4 & - \\
\hline Lk & $29-56$ & 119 & 63.7 & 3.75 & 17 & 8.1 & 7.7 & 812 \\
\hline $\mathrm{Cr}$ & $56-86$ & 59 & 33.3 & 2.06 & 16 & 7.9 & 7.4 & 414 \\
\hline \multicolumn{9}{|c|}{ Transect 2, profile 7 - Limnic-Histosol-Drainic } \\
\hline Oi & $0-50$ & 679 & 328 & 8.02 & 41 & 6.7 & 6.4 & - \\
\hline Lk & $50-80$ & 115 & 62.7 & 3.47 & 18 & 8.0 & 7.6 & 795 \\
\hline \multicolumn{9}{|c|}{ Transect 2, profile 8 - Mollic-Gleysol } \\
\hline Ap & $0-66(81)$ & 143 & 8.9 & 0.81 & 11 & 8.1 & 7.3 & 115 \\
\hline $\mathrm{Cr}$ & $66(81)-86$ & 58 & 2.1 & 0.20 & 11 & 8.1 & 7.4 & 216 \\
\hline $\mathrm{Cr} 2$ & 86-103 & 35 & 0.6 & 0.05 & 12 & 8.2 & 7.2 & 96 \\
\hline
\end{tabular}

Table 2. Properties of soils of transect 3 and 4 by the lake Sumowko (northern part)

\begin{tabular}{|c|c|c|c|c|c|c|c|c|}
\hline \multirow{3}{*}{ Horizon } & \multirow{3}{*}{$\begin{array}{c}\text { Depth } \\
(\mathrm{cm})\end{array}$} & \multirow{3}{*}{ Lol } & \multirow{3}{*}{$\frac{\text { TOC }}{\left(\mathrm{g} \mathrm{kg}^{-1}\right)}$} & \multirow{3}{*}{$\mathrm{Nt}$} & \multirow{3}{*}{$\mathrm{C}: \mathrm{N}$} & \multicolumn{2}{|c|}{$\mathrm{pH}$} & \multirow{3}{*}{$\begin{array}{l}\mathrm{CaCO}_{3} \\
\left(\mathrm{~g} \mathrm{~kg}^{-1}\right)\end{array}$} \\
\hline & & & & & & \multirow{2}{*}{ in $\mathrm{H}_{2} \mathrm{O}$} & \multirow{2}{*}{ in $\mathrm{KCl}$} & \\
\hline & & & & & & & & \\
\hline \multicolumn{9}{|c|}{ Transect 3, profile 5 - Haplic-Gleysol } \\
\hline Ap & $0-22$ & 19 & 8.9 & 0.81 & 11 & 8.1 & 7.3 & 3.9 \\
\hline $\mathrm{Cr}$ & $22-33(38)$ & 12 & 2.1 & 0.20 & 11 & 8.3 & 7.2 & 3.0 \\
\hline $\mathrm{Cr} 2$ & $33(38)-65$ & 03 & 0.6 & 0.05 & 12 & 9.0 & 8.2 & 3.0 \\
\hline \multicolumn{9}{|c|}{ Transect 3, profile 6 - Haplic-Gleysol } \\
\hline A & $0-20$ & 27 & 11.6 & 1.11 & 11 & 8.1 & 7.3 & 17 \\
\hline $\mathrm{Cr}$ & $20-40$ & 16 & 4.5 & 0.34 & 13 & 8.3 & 7.3 & 31 \\
\hline \multicolumn{9}{|c|}{ Transect 4, profile 9 - Colluvic-Regosol } \\
\hline Ap & $0-37$ & 29 & 15.8 & 1.38 & 11 & 8.0 & 7.3 & 3.1 \\
\hline A & $37-60$ & 14 & 5.4 & 0.39 & 14 & 7.9 & 6.9 & 1.7 \\
\hline $\mathrm{Cr}$ & $60-95$ & 13 & 2.1 & 0.16 & 13 & 8.0 & 6.2 & 1.2 \\
\hline \multicolumn{9}{|c|}{ Transect 4, profile 10 - Haplic-Gleysol-Mollic } \\
\hline Ap & $0-20$ & 21 & 11.2 & 1.00 & 10 & 6.0 & 4.9 & - \\
\hline $\mathrm{Cr}$ & $20-40(51)$ & 09 & 5.2 & 0.47 & 11 & 6.1 & 5.4 & - \\
\hline $\mathrm{Ab}$ & $40(51)-62$ & 68 & 42.5 & 3.23 & 13 & 6.3 & 5.6 & - \\
\hline $\mathrm{Cr} 2$ & $62-92$ & 4 & 2.7 & 0.21 & 13 & 7.3 & 7.0 & - \\
\hline $\mathrm{Cr} 3$ & $92-119$ & 19 & 9.5 & 0.21 & 45 & 8.2 & 7.6 & 34 \\
\hline \multicolumn{9}{|c|}{ Transect 4, profile 11 - Colluvic-Regosol } \\
\hline Ap & $0-44$ & 319 & 174 & 13.1 & 13 & 7.0 & 6.4 & - \\
\hline A & $44-56$ & 91 & 54.1 & 5.08 & 11 & 5.6 & 5.0 & - \\
\hline $\mathrm{Cr}$ & $56-79$ & 11 & 6.7 & 0.51 & 13 & 7.8 & 7.2 & 2.5 \\
\hline $\mathrm{Cr} 2$ & $79-89$ & 56 & 42.8 & 2.17 & 20 & 4.9 & 4.7 & - \\
\hline $\mathrm{Cr} 3$ & $89-99$ & 48 & 35.8 & 1.89 & 19 & 5.4 & 5.3 & - \\
\hline
\end{tabular}


that has led to anthropogenic denudation which has played an enormous morphogenetic role in Northern Poland (Sinkiewicz 1990).

\section{Conclusion}

The impact of groundwater level fall owing to lake Sumówko disappear in investigated area has caused transformations of soils of the lake surroundings and led to new soil types formation within the former lake basin. Newly formed soils (Limnic Histosol Drainic and Haplic Gleysol) are mostly utilized as grasslands. The soils of former lake surroundings prove relic properties of gleying and are subject to mucking under dehydration. Lake water level fall has accelerated the rate of colluvial processes due to increase of anthropopression through utilization of new areas for farming purposes.

The areadehydration resulted in emergence of new tillage lands. In reviewed area, conducted reclamation turned out very favourable from agricultural perspective. Water regime of soils circumambient to former lake altered and bottom sediments formed native rock for new soils. Semi-hydrogenic soils evolve into autogenic ones.

All covered soils at present feature high usability virtues exemplified in for instance high content of organic matter (several percent in mineral soils to several dozen percent in rganic ones), propitious reaction (neutral or slightly acidic) and favourable grain size distribution.

Following management of vanished lake catchment lands is advised: the areas situated beyond former lake basin ought to be administered as arable lands while the soils newly formed of bottom sediments perfectly fit to grasslands - as meadows or pastures. Relatively shallowly based level of groundwater $(50$ to $80 \mathrm{~cm}$ ) in the latter would be likely to hamper arable use.

\section{Acknowledgements}

This study was financed by the Ministry of Science and Higher Education of Poland in the form of projects no. N N305 336734 and N N305 283337.

\section{References}

Churski Z., 1988, Naturalne i antropogeniczne przemiany jezior i mokradeł w Polsce (Natural and anthropogenic changes of lakes and wetlands in Poland), Wyd. UMK, Toruń, p. 278 (in Polish).

Gonet S.S., Markiewicz M. (eds), 2007, Rola materii organicznej w środowisku (The role of soil organic matter in environment), PTSH, Wrocław, p. 161 (in Polish, English summary).

[FAO] Food and Agriculture Organization of the United Nations, 2006, Guidelines for soil descriptions, Rome, p. 108.

Kalinowska K., 1961, Zanikanie jezior polodowcowych w Polsce (The Disappearance of Glacial Lakes in Poland), Prz. Geograf. 23(3): 511-518 (in Polish, English summary).

Markowski S., 1980, Struktura i właściwości podtorfowych osadów jeziornych rozprzestrzenionych na Pomorzu Zachodnim jako podstawa ich rozpoznawania i klasyfikacji (The Structure and Properties of Lake Sediment Dispersed on West Pomerania as a Basis for Their Identification and Classification), [in:] Kreda jeziorna i gytie, materiały pokonferencyjne (Lake chalk and gytia. Conference materials), Lubniewice: 44-55 (in Polish).

Marszelewski W., 2005, Zmiany warunków abiotycznych w jeziorach Polski północno-wschodniej. (Changes of the abiotic conditions in the lakes of north-east Poland), Wyd. UMK, Torun, (in Polish, English summary).

Niewiarowski W., 1986, Morfogeneza sandru brodnickiego na tle innych form polodowcowych Pojezierza Brodnickiego (Morphogenesis of Brodnica Outwash Plain Compared to Other Post-glacial Forms of Brodnica Lake District), Acta Univ. NC, Toruń: 3-28 (in Polish, English summary).

Sinkiewicz M., 1998, Rozwój denudacji antropogenicznej w środkowej części Polski Północnej (The Anthropogenic Denudation Developement in the Central Part of Northern Poland), UMK, Toruń, p. 104 (in Polish, English summary).

Tobolski K., 2000, Przewodnik do oznaczania torfów i osadów jeziornych (The Guide for the determination of Peat and Lake Sediments), PWN, Warszawa, p. 508 (in Polish).

[WRB] World Reference Base for Soil Resources, 2006, World Soil Resources Reports 103, FAO, ISRIC, ISSS, Rome, p.128. 